building tightness, the growing use of synthetic materials, and energy conservation measures that reduce the amount of outside air supply," notes a Health Canada technical guide on Sick Building Syndrome.

"We are developing nausea and headaches and general malaise based on air quality," says Newton. "We have sick leaves documented, with each staff person away at about I day every 2 weeks, and that doesn't include the 3 o'clock in the afternoon [moment], where your headache is bothering you to the point where you can't work anymore."

Worksafe B.C. is monitoring the building, but Newton said remedial measures, such as extending the length of the restaurant ventilation system, have thus far proven inadequate. Deborah Jones, Vancouver

DOI:I0.1503/cmaj.071504

\section{Alberta to limit}

\section{self-regulation}

$\mathrm{L}$ egislation that would curb selfregulation by 28 health care professions in Alberta will go to second reading this fall - outraging the province's doctors.

The Alberta Medical Association calls the bill "draconian" and "a threat to selfregulation" that would allow political interference in decisions that should be made only on the basis of evidence and best-practices. "Bill 4I allows the minister to direct the self-regulating body, the College of Physicians and Surgeons, to develop and amend its conduct according to a direction imposed by the minister. It gives him or her the free will to take over the college for no apparent reason," says incoming President Darryl LaBuick.

But Alberta Health and Wellness spokesperson John Tuckwell says the amendments would merely "allow the minister to step in and make changes where necessary, working collaboratively with the health profession bodies."

"It's seen as a last-ditch big stick."

The bill was drafted following outbreaks of antibiotic-resistant bacteria in medical facilities last spring in the towns of Vegreville and Lloydminster. An ensuing review called for new standards of practice by all health professions in infection prevention and control. Tuckwell said Alberta Health Minister Dave Hancock, a lawyer, decided to amend the legislation because "public health trumps all."

During the outbreaks, Hancock "did not have legal authority to step in and make changes where necessary," Tuckwell said. In Alberta's 9 health regions, some hospitals are managed by faithbased organizations that "work ostensibly for health regions ... but have a long standing tradition of independence and autonomy, not working well together.... The minister has proposed provincial standards for infection control [to] help the health professions work together to include these standards across all professions."

But LaBuick says the changes extend well beyond setting standards. "There's no restriction to it, there's no responsibility, no requirement for [regulations] to go through the legislature." He adds that the Bill 4I would allow such political interference as censorship, for example, of a nurse who speaks out about the effect of funding cuts on patient care.

Outgoing Alberta Medical Association President Gerry Kiefer warned in a Sept. 2I letter to members that the legislation empowers the minister to direct the college of physicians and surgeons "to develop or amend its code of conduct according to direction and directives imposed by the minister, direct the college to make bylaws or regulations directed by the minister and dictate the procedures to be followed in developing said code of conduct, bylaws or regulations. Bill 4I would empower the minister to appoint administrators for a college. The minister or cabinet could impose their direction without any oversight by the Legislative Assembly, and this direction could be imposed without the benefit of a full range of knowledge of the profession impacted."

The association's general counsel recently passed a unanimous resolution calling on the minister "to discard the offensive amendments." - Deborah Jones, Vancouver

DOI:Io.I503/cmaj.071534

\section{Slouching toward disclosure}

$\mathrm{T}$ he "culture of non-disclosure" about medical errors that has prevailed in Canada for years is finally beginning to change, says the physician in chief of a major Toronto hospital.

The tendency to instantly invoke "shame and blame" where harm has occurred is slowly disappearing, Dr. Wendy Levinson of Sunnybrook Health Sciences Centre told a Canadian Journalism Foundation meeting on reporting medical errors last month.

"But we're not there yet," Levinson said, arguing that at least part of the reason that a more open system hasn't evolved is simply that most health care providers have not been educated about how to disclose. Levinson noted that at a recent hospital meeting, only 2 of 200 health professionals raised their hands in response to her inquiry about whether they'd received training in disclosing errors to patients. Both had been trained in Australia.

That errors happen and patients suffer harm was and is not at issue. Several panellists at the special session referred to a study indicating that between 9250 to 23750 deaths from adverse events in

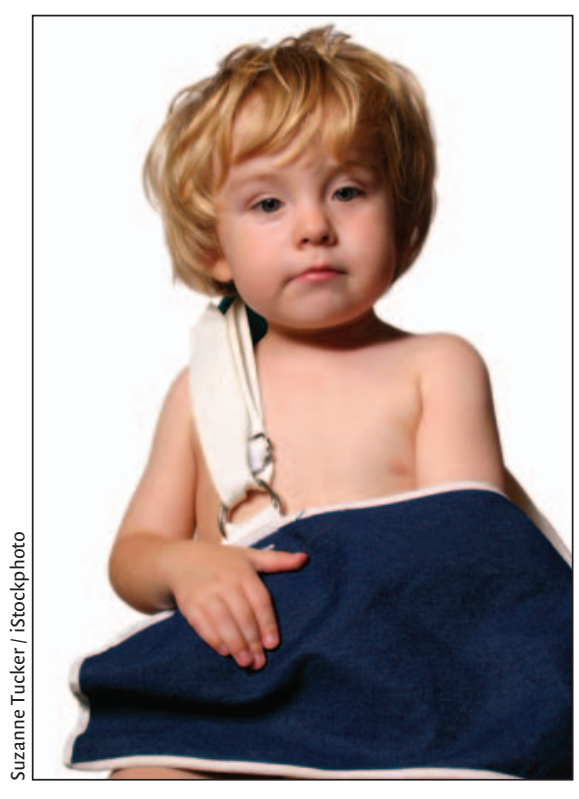

Medical error, adverse event, harm, critical incident, accident, mishap, etc. - there isn't even a consensus on the terminology that most aptly should be applied to medical miscues, miscalculations or mistakes. 